\title{
Israel and the Arab World - Renewal of the Alliance of the Periphery
}

\author{
By Eyal Zisser*
}

During the seventy years of its existence, Israel's relations with the Arab world have experienced a radical turnabout. What began as deadly hostility to the existence of the Jewish state passed over into resignation and a willingness to coexist, even if this was the result of having no choice. Recently, a new stage evolved, with some Arab states willing to develop ties of cooperation that point in the direction of a strategic security alliance. In the 1950s, Israel's partners to the "Alliance of the Periphery," were the non-Arab states on the periphery of the Middle East, which had to confront the rising Arab nationalism of the time and its undisputed leader, Gamal Abd el-Nasser. Sixty years later, the periphery states, or at least Iran, and to some extent, Turkey, have become influential players in the regional arena, in such a way as to represent a challenge to Israel and many of its neighboring Arab states. Israel came into existence finding itself in a prolonged and apparently insoluble conflict with the Arab states, but now, some of the latter have become Israel's partners in face of the Iranian threat and the Turkish challenge. The present "alliance" reflects the changing face of the Middle East and the deep processes it is undergoing. At the head of these is the decline of Arabism and the decline of the Arab world, while on the other side, Iran and Turkey, and Israel too, are rising in influence and power. Indeed, it is these three countries that today dictate the path the Middle East will take.

Keywords: Israel, Iran, Turkey, Saudi Arabia, Egypt.

\section{Introduction - The Middle East in the Shadow of the Rivalry between Iran and Israel}

In mid-winter of 2010 the "Arab Spring" broke out and spread all over the Arab world. It undermined the stability of many Arab countries and even toppled some regimes that had ruled with an iron fist for decades. At its height, it even brought into question the validity of the borders on the map of the Arab Middle East, which had been fixed by the 1916 "Sykes-Picot Agreement" and held up during the whole course of the 20th century. For a moment, it seemed as if the Arab world was following in the footsteps of other parts of the world, like Eastern Europe or South America, where restless young people led processes of change and even democratization.

However, the Middle East has its own way of doing things. The initial progressive liberal upsurge was replaced by an Islamic tendency advanced by the Islamic forces in region, and the initial protests and revolutions degenerated into bloody civil wars. These led to instability, dangerous insecurity, and in

\footnotetext{
*Professor and Vice Rector, Tel Aviv University, Israel.
} 
some cases complete chaos. Finally, nearly a decade later, the storm of protest, rebellion, and revolution triggered by the "Arab Spring" has subsided. Many Arab states, like Tunisia and Egypt, returned to the same situation they had known before the storm struck. In other states, like Yemen and Libya, the "Arab Spring" ultimately led to the collapse of the state institutions and a situation of prolonged anarchy, which still prevails at the time of this writing (Lynch 2012).

In its early stages, the "Arab Spring" was perceived as a positive and welcome outburst of vitality that would lead to a revival of Arabism, that is, the promotion of Arab unity, culture, and identity. The uprising was seen as an expression of the young Arab generation's determination to put the Arab world, and in particular, its Sunni segment, back on the map after several decades during which Arab states sank into themselves (Korany 2012). They had done so in large part on account of the social and economic hardships they suffered and the intervention in their affairs of foreign players, both international and, especially, regional, like Iran, accompanied by Turkey.

Iran was perceived as the state most likely to lose its status or, at the very least, to be damaged by the "Arab Spring". After all, Iran had been working for many years already to become a leading power and source of influence all over the Middle East, and beyond as well, by exploiting the weaknesses of the Arab countries. Many observers in the region tended to view Iran as the representative of the Shi ite Muslims, so its rise to prominence was considered to be a manifestation of the strengthening of the Shi ite camp in the world of Islam. The "Arab Spring", however, which, as noted, was initially perceived as an effort to restore the glory of Arab culture and identity, looked like it would damage and perhaps even block Iran's efforts to increase its influence in the Middle East (Tisdall 2011).

Israel was also perceived as an actor that would be damaged by the "Arab Spring". This was because the upheavals led to the collapse of regimes that were considered to be allies of Israel, and first of all, the regime of Egyptian President Hosni Mubarak. The trend that soon emerged and witnessed Islamic movements strengthening their position - like the Muslim Brotherhood, which seized power in Egypt and held it for almost a year - was also viewed as a development packed with negative and threatening implications for Israel (Friedman 2011).

However, ultimately, the "Arab Spring" not only failed to lead to setbacks for Iran or Israel, but on the contrary, enabled them to improve their status in the region. Both proved wise enough to exploit the chaos and the void created in the wake of the "Arab Spring" events. Thus, Iran took advantage of the chaotic local situations in Iraq and Syria, and in Yemen as well, to gain a foothold. This strengthening of Iran was perceived by many Arab states, first and foremost, the Gulf states led by Saudi Arabia, as a threat to themselves. They thus turned to Israel, which they viewed as an important regional player and even as a possible ally and strategic partner vis-à-vis the growing threat from Teheran.

This contributed to bringing about the establishment of a strategic alliance between the Jewish state and several of the Arab states, led by Saudi Arabia and some of the Gulf States, as well as Egypt and Jordan. This alliance, based upon common interests, is quite reminiscent of the "Alliance of the Periphery" 
established toward the end of the 1950s, although, perhaps ironically, as its exact reverse. The 1950s version called for Israel to develop close strategic alliances with non-Arab Muslim states in the Middle East (in particular, Turkey, prerevolutionary Iran, and Imperial Ethiopia) to counteract the united opposition of Arab states to the existence of Israel and the rising power of Egyptian President Gamal Abd al-Nasser, in particular. In stark contrast, the present version of the alliance is not directed against Egypt. Rather, Egypt is one of its important Arab partners. All the members are united by their fear of Iran's ambitions, and perhaps also by their resentment of Turkey's ambitions for hegemony, and by their desire as well to combat and put an end to the Islamic terror that has arisen in the Arab lands. It goes without saying that this new alliance received additional impetus and significance due to United States President Donald Trump's decision to withdraw American forces from Syria. Trump took this step as part of the general process of detaching the U.S. from the Middle East that began during the previous Administration of U.S. President Barack Obama.

True, the current alliance between Israel and some of the Arab states has limitations and weaknesses, and a kind of glass ceiling that the participants will find it difficult to overcome, especially in the absence of any progress in the Israeli-Palestinian peace process. Still, from this new alliance we can learn a great deal about the changing face of the Middle East and the transformation of Israel's relations with the Arab world. The latter have passed from opposition and hostility to reconciliation and a preparedness to coexist, and from there to cooperation up to the point of forming a strategic alliance. This alliance, moreover, opens the possibility of laying the foundations for wider regional cooperation in the Mediterranean Basin, for both Israel and the Arab countries. Thus, for example, both Israel and Egypt have strengthened their ties with Cyprus and Greece.

\section{Israel and the Arab World - from War to Peacemaking}

In May 1948, the British Mandate on Palestine ended and the State of Israel was born. According to the partition resolution of 1947 an Arab state was to be established alongside it, but never was. Since its' born, Israel's place in the Middle Eastern system and its relations with surrounding Arab countries have been the focus of research by Israeli and Arab researchers as well as researchers from outside the region. The question at stake was a complex one, involving political, ideological and cultural layers. It was political scientists who as early as the 1950's and 1960's laid the theoretical foundations for examining the Middle East as a separate entity, a separate system or an "international subordinate system" with its own characteristics and modes of operation (Binder 1958, Cantori and Spiegel 1970). Those included Israel as a legitimate player in the system. Subsequent researchers considered Israel's Involvement in the inter-Arab system on the basis of the assumption that the role Israel plays in that system is at once unifying and separating, stabilizing and intervening (Perry 1984, Podeh and Kaufman 2006). 
Israel's birth in May 1948 was preceded by a violent conflict between the Jewish and Arab populations of British Mandate Palestine that started already in November 1947 following the adoption of the partition plan by the UN. When the new state declared its independence it was invaded by the armies of the surrounding Arab states. The 1948 war ended with a severe defeat for the Arab side. Hundreds of thousands fled, and some were expelled, from the territory that became the State of Israel. They became refugees who settled all over the Arab world, and until this very day no solution has been found for them, whether by returning to the places of their birth, or moving to the territories governed by the Palestinian Authority, or becoming settled in the countries where they presently reside.

The War also ended in the defeat of the regular armies of the Arab states that invaded the Jewish state. The fighting ended in 1949 with the signing of shaky Armistice Agreements with the Arab states of Egypt, Lebanon, Jordan, and Syria. The agreements did not prevent the continuation of hostile and violent acts during the following years, mostly by refugees or Palestinian fighters (Fedayeen) who penetrated into Israeli territory (Rabinovich 2003).

The next round of fighting between Israel and the Arabs, or more precisely, Egypt, the biggest Arab country, was in 1956. Israel joined Britain and France in their efforts to overthrow the regime of Egyptian President Gamal Abd elNasser, following his decision to nationalize the Suez Canal and draw close to the Soviet Union. Israel defeated the Egyptians in the military conflict in the Sinai desert. This led to significant political achievements for the Jewish state. First of all, a shipping lane was opened up through the Red Sea to Israel's southern port town of Eilat. In addition, United Nations Observers were deployed along the Israeli-Egyptian border to ensure the quiet. At the same time, however, Nasser improved his status in the Arab world. This was because he was perceived as the victor in the confrontation with England and France, the two colonial powers that had ruled the Middle East high-handedly in the past. After all, Nasser had succeeded in remaining in power despite their attack, and he was able to compel his attackers to withdraw their forces from Egyptian territory (Louis and Owen 1991).

\section{The "Alliance of the Periphery"}

One can understand why the 1950s are considered Nasser's greatest hour, as well as a glorious moment for Arab nationalism. Under Nasser's leadership Arab ideology became predominant throughout the region; millions embraced it. For a while it even seemed as if there was no power that could prevent Nasser from establishing himself, or at least his influence, over the whole Arab world (Vatikiotis 1978).

Israel's Prime Minister, David Ben-Gurion, became gravely concerned in face Nasser's rising popularity and the increasing influence of the Arab nationalism he advocated. Ben-Gurion thus sought other states that felt the same threat and would be willing to cooperate with Israel against Nasser. He found such allies in states on the region's periphery: Ethiopia in the south, Turkey in the north, and Iran in the 
east. Some Arab monarchies, like Morocco and Saudi Arabia, also established very clandestine, and sometimes indirect, affiliations with Ben-Gurion's already relatively covert alliance (Alpher 2015).

The "Alliance of the Periphery" had its own limitations. Each of the partners was relatively weak, especially in face of Nasser's rising power. Furthermore, their willingness to cooperate with each other was limited from the very beginning. Still, the Alliance did give its members some feeling of security, and even some tactical advantages. Thus, for example, the partners exchanged intelligence information about the Egyptian ruler's intentions. In some instances, they even assisted each other in supplying weapons. For example, during the 1958 civil war in Lebanon, Israel enabled Iran to transfer weapons via Israeli territory to the Shi ites in south Lebanon. The aim was to encourage the Shi ites to support the pro-Western administration of Lebanese President Camille Chamoun against his opponents, most of whom supported the pro-Nasser camp in the country (Erlich 2000). Later, in the early 1960s, Israel granted indirect assistance to rebels in Yemen in their war against Nasser, with the closed-mouth knowledge of Saudi Arabia. Indeed, the Saudis were the main supporters of the Yemeni rebels in their struggle against Nasser at the time (Orkaby 2015).

It was clear, however, that the "Alliance of the Periphery" was incapable of changing the regional situation fundamentally. This was not a formal alliance institutionalized by agreements. It remained relatively covert and secretive. In general, the sides maintained secrecy, being concerned that publicity would only harm them. Insofar as Israel was concerned, even though it was one of the major factors urging the establishment of the alliance, this was not enough to affect its status in the region, so it remained a marginal, and even weak, player.

We note that apart from all this, it seems that there was a great deal of exaggeration in the perception of Nasser as all-powerful and a threat to regional stability. After all, his high point in late 1956 was also the starting point of his decline. That decline did not begin in the wake of the June 1967 Six Day War defeat, but rather much before this, on account of Nasser's failure to resolve Egypt's social and economic problems or achieve Arab unity throughout the Arab world. In any case, the weakening of Nasser and the decline of Arabism found clear expression in the Arab defeat of June 1967. The "Alliance of the Periphery" now became superfluous from the point of view of both Israel and its partners. Some of the latter, like Saudi Arabia and Iran, even began to improve their relations with Egypt, which ceased being perceived as an enemy.

We should note in passing that the "Alliance of the Periphery" was just one aspect of Israel's much broader efforts to find allies in the region and outside it. In addition to establishing ties with the "Periphery Alliance" states, Israel also developed ties, and even extended assistance, to other actors. The Kurds in Iraq, who were fighting the regime in Baghdad, were one of these. The black Christian majority of South Sudan, who were fighting the central government in Khartoum, also received Israeli aid. In Lebanon, Israel continued its long-term efforts to establish ties with a number of the various forces in the country, but mainly with parties in the Maronite camp. 


\section{The Decline of Arabism, the Weakening of the Arab States, and the Rising Power of Iran and Turkey}

The late 1960s were marked by the decline of Arabism as a leading force in the Arab world. Egyptian President Nasser's death in September 1970, and even before this, the defeat suffered in the Six Day War, heralded the end of the era of Egypt's efforts to gain influence and even hegemony over the Arab world. The ideology of Arabism, which failed in both its efforts to bring about the unification of the Arab people and to defeat Israel, was replaced by competing ideologies and worldviews, the leading one being Islam. The weakness of Arabism stemmed mainly from the fact that all the Arab countries were becoming ever more embroiled in their domestic social and economic problems. This led each Arab country to concentrate on and give preference to its own particular state interests at the expense of all-Arab interests (Ajami 1978). The result was limited readiness, at least among some of the Arab states, to settle the conflict with Israel and advance mutual political and even economic relations (Sela 1998).

The first Arab state to act in this direction, as is well-known, was Egypt, in the late 1970s, under the leadership of President Anwar Sadat. He went so far as to sign a peace agreement with Israel. The new situation also found expression in the Arabs' willingness to take part in the Arab-Israeli peace process initiated by the United States at the beginning of 1991, after the liberation of Kuwait from Iraq in the Gulf War. The first major event in the peace process was the October 1991 Madrid Conference. It led to the Israeli-Jordanian Peace Treaty (signed in 1994) and the Israeli-PLO Oslo Accords (signed in 1993 and 1995). In the late 1990s, however, the Israeli-Palestinian peace process had run into difficulties on account of the unbridgeable gap between the positions of the sides to the conflict (Quadnt 2005).

Israel was not the only player to benefit from the changes taking place on the map of the Middle East early in the $21^{\text {st }}$ century. During the first decade, two old-new regional powers came to prominence in their efforts to advance their standing in the region, namely, Turkey and Iran. These states are perceived in the region as heirs to two older, long-lived, and rival empires, Turkey, heir to the Ottoman Empire, and Iran, heir to the Persian (Safavid, then Qajar) Empire, which ruled over and battled for dominance in the Middle East for nearly 500 years, from the beginning of the $16^{\text {th }}$ century. World War I put an end to the two old empires, as Britain and France became the dominant powers in the region.

In recent decades, however, Iran and Turkey seem to have gained the opportunity to renew their greatness. Turkey's fate became linked with Recep Tayyip Erdogan, the charismatic leader of the AK Parti. He has succeeded in providing Turkey with political stability, and under its umbrella, with economic prosperity as well. Unlike the leaders of previous Turkish governments, in fact, unlike all the governments since the days of Mustafa Kemal Atatürk, founder of the modern Republic of Turkey in 1923, Erdogan views the Arab and Muslim lands as a preferred field of action. He attempts to exploit the Muslim character of his political party and the weaknesses of the Arab states, as well as the fact 
that Muslim parties associated with the Muslim Brothers have gained strength in them, in order to promote Turkey's position in the Arab world.

Iran also seeks to benefit from the changes occurring in the Middle East. For many decades, going back at least to the time of the Shah, before the ayatollahs, or perhaps even earlier, Iran has had aspirations to gain influence, and even hegemony, over the region, or at the very least, to establish a security belt stretching from the Iranian Heights to the Mediterranean Sea. It goes without saying that Iran benefitted from both of the United States' wars in the region, in Afghanistan (winter of 2001) and Iraq (spring of 2003). This is because the Taliban regime in Afghanistan and Saddam Hussein's regime in Iraq were both tough foes of Iran, and as if in a flash they were eliminated by Washington (Saikal 2019).

Since Iran is a Shi ite country acting in the name of Shiite Islam and expressing commitment to the export of the Islamic revolution to Shi ite communities in the region, its rise to greatness was and is perceived as the rise of that school of Islam at the expense of the Sunni Islam world. Saudi Arabia and other gulf states thus feel threatened on two fronts, first, by the fact that Iran is intervening in the affairs of the Shi ite communities in the Persian Gulf states, including their own, and second, by the clearly alarming fact that Iran is developing nuclear capabilities.

In view of Iran's rising many of the moderate Arab states, like those of the Gulf, started manifesting a greater willingness to expand cooperation with Israel. They became more open to accepting economic assistance and developing security arrangements vis-à-vis Iran. In fact, an Israeli-Gulf state dialogue was begun as early as the 1990s, in the shadow of the Israeli-Arab peace process being advanced by the U.S. In the framework of that dialogue, channels of political and security cooperation were opened between the two sides and trade and economic ties expanded greatly. Two of the Gulf states, Oman and Qatar, opened diplomatic offices in Israel and allowed Israel to establish similar offices on their territory. At the same time, other Arab states began establishing channels for dialogue with Israel (Miller and Zand 2018).

Toward the end of the 1990s, the Israeli-Palestinian peace process came to a dead end. The failure to advance Israeli-Palestinian peace agreement, was followed by a renewal of rounds of violence between the latter two sides. All this blocked, and even set back relations between Israel and the Gulf states, which made it clear that the weak point in their relationship with Israel was their concern over how matters between Israel and the Palestinians were proceeding. Still, the lines of communication were not closed completely. The Gulf states, led by Saudi Arabia, continued in their efforts to put the peace process back on track. In this context, they placed various proposals on the table, the most prominent of which was the Arab Peace Initiative of 2002 (Fuller 2002). The warming relations with Israel found expression sometime later, in the summer of 2006, during the Second Lebanon War between Israel and Hezbollah. Many Arab states almost openly supported Israel in this fight.

Insofar as the Gulf States were concerned, the challenge was right in the Gulf itself, where Iranian antagonism was increasing perceptibly. It seems that 
these tangible difficulties with Iran served as the background for several Gulf States, led by Saudi Arabia, opening channels for dialogue with Israel, and even deepening and expanding them. There were reports, for example, of a meeting between senior Israeli officials, including then-Prime Minister, Ehud Olmert, and senior Saudi officials, including perhaps Prince Bandar bin Sultan. It was also reported that Mossad Head Meir Dagan visited the Saudi capital, Riyadh. Against this background, media reports multiplied about the development of cooperation and security coordination between Israel and Saudi Arabia in connection with the possibility of Israeli military action against Iran's nuclear facilities. Both sides hastened to deny these reports or refused to relate to them (The Guardian 2006).

\section{The "Arab Spring" and Its Failure}

The shockwave that overcame the Arab world during the winter of 2010 was unlike anything it had known for decades. Soon after it began this outburst of turbulence was termed the "Arab Spring." The use of this term reflected the high hopes, and even faith, of many in the Arab world and elsewhere for positive change. They hoped that the upheaval would lead to the collapse of the political and social arrangements existing in most, if not all, of the Arab states, which suffered from various serious maladies and defects. They hopeful looked forward to progress in the direction of democracy and enlightenment, political stability and economic prosperity, security and social justice.

The turmoil began in Tunisia and from there skipped over to Egypt. After them came the turn of Libya, Yemen, and finally, Syria. In Tunisia and Egypt the reigning presidents, Zayn Abadin Ben Ali and Hosni Mubarak respectively, fell from power. For a while, Islamic parties managed to take power. In the end, however, both Tunisia and Egypt returned to the same point they had been at the outbreak of the "Arab Spring". In Tunisia secular forces, some of which had held power under Ben Ali, returned to power. In Egypt the army came back and took control. This occurred in June 2013, when a military coup d'état led by the Minister of Defense, Abd al-Fattah El-Sisi, overthrew the regime of Muslim Brotherhood adherent, Mohamed Morsi. Sisi became president of the country. By contrast, the collapse of the ruling regimes in Libya and Yemen, brought about by the "Arab Spring", led to the collapse of their whole state systems and the outbreak of bloody civil wars.

In Yemen, in September 2014, forces loyal to the Houthi movement took over the government in the capital, Sana'a. The Houthi belong to the Shiite branch of Islam and are named after their founder, Hussein Al-Houthi. Iran became the main supporter of the Houthi in their battle for control of Yemen. The nightmare of the Saudis thus came to life, that is, their fear that Yemen, which is right in the Kingdom's backyard, would become a forward base for Iran. From there, very close by, Iran could threaten to fire missiles on Saudi cities. It could also try to block shipping in the Bab-el-Mandeb strait at the mouth of the Red Sea. 
Because of their concerns about Iran's deepening intervention on the side of the Houthi in Yemen and the aid it was giving to the Hezbollah organization on their territory, the Gulf states were moved to unify under the leadership of Saudi Arabia (Lewitt 2016). In March 2015 they launched the "Determination Storm Operation", which aimed, by means of attacks from the air, at blocking the Houthi takeover of Yemen and depriving the Iranians of the grip they hoped to achieve over the southern Arabian Peninsula and the entrance to the Red Sea. However, the Saudis failed to achieve a complete victory, and Yemen sank into a prolonged state of war, with the price being paid, as usual in the Middle East, by the civilian population of the country (Gordon 2018).

In Syria, President Bashar al-Assad survived the upheaval of the "Arab Spring", but in his struggle for survival he dragged the country into a prolonged and bloody civil war. The price paid was very high. Over half a million Syrians were killed and millions more became refugees. Bashar al-Assad's victory was finally achieved thanks to the involvement of Russia and Iran in the fighting, beginning in September 2015. While Russia struck at Assad's opponents from the air, Iran sent tens of thousands of fighters into Syria, some of them Shiite volunteers gathered from all over the Muslim world, including Iraq, Afghanistan, and Pakistan. Iran made no secret of its intention to establish its presence in Syria, which would continue even after the war ended. The aim was to make Syria part of the long-coveted land corridor leading straight from Tehran to Baghdad, then to Damascus and Beirut, thus establishing Iranian hegemony over this whole expanse (Harris 2018).

The outbreak of the "Arab Spring" was accompanied by the beginning of the end of a long period of "Pax Americana" in the Middle East. This had begun in the spring of 1991, in the wake of the Gulf War of that year, and gathered force with the collapse of the Soviet Union in December 1991. As the "Arab Spring" and the turmoil it produced were happening, America, under Presidents Obama and Trump, sought to detach itself from the region and its problems. In contrast to Washington, Moscow, under the leadership of President Vladimir Putin, found a way to return to the region and play a major role in redrawing its map and determining its character, in a manner that coincided with Russia's interests and age-old historical goals in the Middle East.

Russia did not act in a vacuum or as the only player in the Middle East arena. Serving the Russians as a platform and assistant were Iran and its proxies, all of whom were and are participants in the "radical axis," or "Shi ite axis," that took shape during the previous few decades. As we know, many in the region and abroad sought to see the "Arab Spring" as an expression of an awaking, or even rebirth, of the Sunni Arab expanse in face of the Shiite challenge that had risen up before it. The role Shi ite Iran was able to play in Syria (and elsewhere), however, meant that not only did the "Arab Spring" fail to bring about a weakening of the "Shi ite axis", but, on the contrary, reinforced it. Standing at the side of Russia and cooperating closely with it, Iran became an important player in wide areas of the Middle East (Bolan 2018).

In retrospect, then, it is clear that the Arab Spring actually strengthened Iran, which found a way, with the help of Russia, to exploit the disorder in the 
region in order to advance its own interests in Iraq, Syria, and Yemen. It is no wonder that Iran's moves caused anxiety in the Gulf States. In the face of Washington's tendency to disengage from the Middle East, the anxiety increased. As noted, the U.S. withdrawal began during the time of the Obama Administration, and President Trump has continued it at full speed. Obama was prepared to come to an agreement with Tehran on the nuclear question and did not conceal his desire to avoid using American power against Iran or anywhere else in the Middle East. Trump, for his part, decided to remove the American troops in Syria, thereby leaving most of that country to Russia and Iran, and the northern part to Turkey. Even as it withdrew the U.S. paid lip service to the leaders in the region, saying it would continue to be committed to their security. However, the fear that they could no longer rely on Washington to come to their aid pushed some of the Arab states, in particular the Gulf States, into the arms of Israel. At the same time, they also made efforts to strengthen their ties with Moscow (Hall 2019).

At this point we should note the role of Turkey, which is a large Sunni Muslim, but non-Arab, state. It could have served as the axis of a broad regional undertaking by the moderate and pro-Western Sunni states to stand up against and block Iran. However, that is not what happened. Turkey, in pursuit of its own interests, attempted to exploit the "Arab Spring" and later even ride the Islamic wave that inundated the Arab states for a while. Thus, the defeat of the Muslim Brothers in Egypt, Tunisia, and Syria was also a defeat for Turkey, which ended up only partially satisfied, having limited control over an area in northern Syria (Schanzer and Tahiroglu 2016).

Over and over again Turkish President Erdogan subjected his country's foreign policy to his own personal whims or his personal political interests, and his whimsical moves prevented Turkey from taking advantage of the on-going crisis to strengthen its position. This happened even though Ankara was not at all happy about its largest regional and Shiite competitor, Iran, growing stronger.

Characteristic of Turkey's behavior were the policies it adopted towards Israel and Egypt, both important regional players. Because of the way Turkey tried to use the Palestinian question, its relations with Israel became badly muddied. There was even a long break in relations because of the 2010 Turkish ship MV Mavi Marmara incident and Erdogan's subsequent wildly anti-Israel rhetoric. Regarding Egypt, Erdogan's refusal to recognize the legitimacy of the military coup led by Abdel El-Fattah El-Sisi against the government of the Muslim Brothers resulted in a rift and then a break in relations between the two countries.

The threating shadows cast by Iran and, in the view of some, Turkey, made it imperative for Israel and other nearby countries to increase their cooperation with each other. As in the old "Alliance of the Periphery" of sixty years previously, now too there was no institutionalized or formal alliance, but rather a series of collaborations, mostly relating to intelligence and security matters.

It should be noted that initially Israel took advantage of the war in Syria to attack and destroy weapons shipments from Iran to Hezbollah on Syrian soil, and later, also to attack installations representing Iran's efforts to establish 
bases on Syrian territory. Israel was successful, at least in part, insofar as Iran showed its unwillingness to enter into a direct and all-out confrontation with Israel by slightly withdrawing its forces from the Israeli-Syrian border. The determination shown by Israel in its struggle against Iran's becoming firmly based in Syria as well as its determination in its struggle against Iran's nuclear ambitions has been perceived by other countries as a success and an example to be imitated, and they are inspired by Israel's willingness to confront Iran (Ayman 2018).

Thus, Israel and Egypt have begun cooperating militarily to an unprecedented degree and closely coordinating their fight against the ISIS threat in Sinai. The Egyptian public has not changed its attitude toward Israel, but the Egyptian government has become committed and even willing to cooperate in military matters more than ever before. Thus, for example, it has been reported that Israel, in coordination with the Egyptian army, has attacked targets in Sinai manned by the ISIS branch there, and that Israel helps the Egyptian Army with intelligence in its war against the radical Islamists (Saleh 2019, Al-Jazeera 2019).

A political dimension has also developed in this expanding field of cooperation. For example, Israel showed its willingness to intervene with the Americans on the Saudis' behalf in the case of the killing of the Saudi journalist, Jamal Khashoggi, whose death was being blamed on the heir to the throne, Crown Prince Mohamed bin Salman. From their side, most of the Gulf states stood on Israel's side at the Warsaw "Conference on Peace and Security in the Middle East" sponsored by the U.S. in February 2019 (Holmes 2019). The Gulf States and many other Arab countries were also willing to be enlisted to help in the Americans' effort to promote an Israeli-Palestinian peace process, in order to remove this issue from the regional agenda. It has been reported in the media that these countries have been putting a lot of pressure on the Palestinian Authority, headed by Mahmoud Abbas, to cooperate with the efforts of the Trump Administration to advance its so-called "deal of the century," the American draft proposal for solving the Israeli-Palestinian conflict (Krasna 2018).

Economic relations must also be added to this expanding field of IsraeliArab cooperation. This economic dimension developed thanks to the discovery of natural gas fields along the Mediterranean coastline close to Israel. It was the first to discover and exploit these gas fields, which turned it into an important player on the international scene. Thus, Israel became the supplier of gas to Jordan after having already taken upon itself the obligation to supply the Kingdom with water. Israel also signed agreements to supply gas to Egypt (Macaron 2019). At the same time, efforts to make use of these discoveries for the purpose of improving relations with Turkey did not fare well. Because of Erdogan's hostility, no agreement to export Israeli gas to Europe via Turkey could be reached. As a substitute, Israel chose Greece and Cyprus as channels for exporting its gas to Europe. This economic decision was, in fact, part of a deeper system of ties that were being established between Israel and the two Greek-speaking countries, thanks in large part, undoubtedly, to their concerns over the challenges posed to them by Erdogan-led Turkey (Karbuz 2017). 
Similar to its behavior in the 1950s, Israel in the 2010s began to put together a system of relations with other countries that moved in the direction of a genuine regional alliance in face of the threats and dangers it and they saw themselves facing. As in the 1950s and 1960s, this was a system of relations, not an institutionalized alliance. However, there are clear differences between the 1950s and today. Israel today is a much more powerful and influential regional player than it was then, thanks to its economic and military strength and its relations with the rest of the world. The old 1950s "Alliance of the Periphery" arose at a time when Israel's relations with the U.S. were quite unstable. Today, in contrast, Israel is perceived as a close, solid, and even intimate ally of the American Administration.

In addition to maintaining ties with other actors inside the region, like the Kurds and the South Sudanese, historical allies of Israel, the Jewish state is also working to tighten its relations with Cyprus and Greece, as mentioned previously. Here Israel has an economic and a security interest. It wants to work with the Greek-speaking countries to develop energy resources, and especially the gas fields off the Mediterranean coast. Indeed, there are those who view Israel's relations with such countries as Azerbaijan, Greece, Cyprus, Ethiopia, and South Sudan, and even with other countries in Asia and Africa, as the real analogy to the "Alliance of the Periphery". Finally, there are also observers who would add to the above Israel's friendship with the states of the Visegrád Group (also known as the Visegrád Four or V4, a cultural and political alliance of the Central European states, Poland, Hungary, Slovakia, and the Czech Republic). The friendly relations with the latter came about thanks to the good personal relationships developed by Israel's Prime Minister, Benjamin Netanyahu, with the heads of state of the V4, but also thanks to those leaders' lack of trust in Brussels (as the capital of the European Union) (Ahren 2019).

\section{Conclusion}

During the seventy years of its existence, Israel's relations with the Arab world have experienced a radical turnabout. What began as deadly hostility to the existence of the Jewish state passed over into resignation and a willingness to coexist, even if this was the result of having no choice. Recently a new stage evolved, with some Arab states willing to develop ties of cooperation that point in the direction of a strategic security alliance.

In the 1950s Israel's partners were the non-Arab states on the periphery of the Middle East, which had to confront the rising Arab nationalism of the time and its undisputed leader, Gamal Abd el-Nasser. Sixty years later, the periphery states, or at least Iran, and to some extent, Turkey, have become influential players in the regional arena in such a way as to represent a challenge to Israel and many of its neighboring Arab states. Israel came into existence finding itself in a prolonged and apparently insoluble conflict with the Arab states, but now some of the latter have become Israel's partners in face of the Iranian threat and the Turkish challenge. 
Like the old "Alliance of the Periphery", the current cooperation is marked by clear limitations. First, there is the lack of ability and, it seems, a lack of willingness as well, to make the existing ties public. There is also a lack of willingness to advance beyond the development of security ties between the states' rulers and security establishments to the stage of normalization and a warm peace between the sides.

The present "alliance" reflects the changing face of the Middle East and the deep processes it is undergoing. At the head of these is the decline of Arabism and the decline of the Arab world, while on the other side, Iran and Turkey, and Israel too, are rising in influence and power. Indeed, it is these three countries that today dictate the path the Middle East will take.

The main focus at present is on Iran, but Israel and a number of the Arab states have shared political and security interests apart from Iran. In addition, there is the possibility of expanding the existing cooperation beyond the political aspects that touch the states of the Middle East exclusively. This is attested to by the fact that states like Cyprus and Greece are willing to participate in a direct alliance with Israel and economic cooperation with Egypt.

This development may have been accelerated by the Arab Spring but is not its direct result. It's focus is the conflict with Iran but it has the potential to develop beyond it, as the players involved have political and security interests in common. The involvement of countries such as Cyprus and Greece in a direct alliance with Israel and the economic involvement of Egypt, too, indicate the ability to extend this cooperation to issues beyond political aspects relevant to the Middle East alone .

Should Israel and its partners in the set-up of alliances and understandings now taking place in the Eastern Mediterranean conduct themselves wisely, stability in the region may be enhanced, and efforts for peace promoted. It might also yield significant economic revenues to all regional players. At the same time, should the status quo be preserved instead of moving ahead peace efforts, or even serve as the basis for a provoking or confronting common rivals, like Iran, rather than deter them, the result might be instability in the region that can be developed into rounds of violence. Such a pessimistic scenario might destabilize the foundations of the new peripheral alliance Israel had established with its neighbors which in any case has its limits, to begin with the fact that its being based more on particular interests of regimes and countries and lacks wide public support, as distinct from acceptance, at least on the part of public opinion in the Arab world.

\section{References}

Al-Jazeera (2019) Sisi: Egypt, Israel in close cooperation against Sinai fighters. Retrieved from https://bit.ly/2GwZVz2. [Accessed 5 January 2019]

Ahren R (2019) Israel to host 4 Central European leaders, including Hungary's Orban, Visegrad Group's February summit in Jerusalem marks first meeting of consortium outside of Europe. The Times of Israel. Retrieved from https://bit.ly/2W2nxSC. [Accessed 28 January 2019]. 
Ajami F (1978) The End of Pan-Arabism. Foreign Policy. Winter 1978/79 Issue. Available at https://www.foreignaffairs.com/articles/yemen/1978-12-01/end-pan-arabism.

Alpher Y (2015) Periphery, Israel's Search for Middle East Allies (Hebrew). Tel Aviv: Matar Publishing House.

Ayman DI (2018) Will Israel and Iran go to war in Syria? The Brookings Institute. Retrieved from https://brook.gs/2SAnITc. [Accessed 5 October 2018].

Binder L (1958) The Middle East as a subordinate international system. World Politics 10(3): 408-429.

Bolan, C. J (2018). Russian and Iranian "Victory" in Syria: Does It Matter?. The Foreign Policy Research Institute. Retrieved from https://bit.ly/2SyUPax. [Accessed 20 December 2018].

Cantori LJ, Spiegel SL (1970) The International Politics of Regions: A Comparative Approach, 1-41. Englewood Cliffs, NJ: Prentice-Hall.

Erlich R (2000) The Lebanon Tangle, The Policy of the Zionist Movement and the State of Israel towards Lebanon, 1918-1958 (Hebrew), 488-491. Tel Aviv: Ma'arachot.

Friedman TL (2011) Postcard From Cairo, Part 2. The New York Times. Retrieved from https://www.nytimes.com/2011/02/13/opinion/13-friedman-Web-cairo.html. [Accessed 13 February 2011].

Fuller GE (2002) The Saudi Peace Plan: How Serious. Middle East Policy Council, Volume IX, Number 2. Available at https://www.mepc.org/saudi-peace-plan-howserious.

Gordon P (2018) Saudi Arabia's war in Yemen has failed. The Washington Post. Retrieved from https://wapo.st/2L6pZqy. [Accessed 12 November 2018].

Hall R (2019) Trump Says Syria is 'Sand and Death' in Defence of Troop Withdrawal. The Independent. Retrieved from https://ind.pn/2XvwvIu. [Accessed 3 January 2019].

Harris W (2018) Quicksilver War, Syria, Iraq and the Spiral Conflict. London: Hurst.

Holmes O (2019) Do Netanyahu's Smiles with Arab leaders Signal a New Era?. The Guardian. Retrieved from https://bit.ly/2DFIWZY. [Accessed 14 February 2019].

Miller AD, Zand H (2018) Progress Without Peace in the Middle East. The Atlantic. Retrieved from https://bit.ly/2KUqB2h. [Accessed 1 November 2018].

Saleh H (2019) Egypt tries to block airing of Sisi's '60 Minutes' interview. Financial Times. Retrieved from https://www.ft.com/content/320a08d0-11bc-11e9-a581-4ff7840452 4e. [Accessed 6 February 2019].

Karbuz S (2017) East Mediterranean Gas: Regional Cooperation or Source of Tensions?. Barcelona Center for International Affairs, May 2017. Available at https://www.cido b.org/es/publicaciones/serie_de_publicacion/notes_internacionals/n1_173/east_medit erranean_gas_regional_cooperation_or_source_of_tensions.

Korany B (2012) Egypt and beyond: The Arab Spring, the New Pan-Arabism, and the challenges of transition. In B Korany, R El-Mahdi (eds) Arab Spring in Egypt: Revolution and Beyond. Cairo: Cairo University Press. Available at http://cairo.uni versitypressscholarship.com/view/10.5743/cairo/9789774165368.001.0001/upso-978 9774165368-chapter-14.

Krasna J (2018) Israel and the Gulf States: Some Things Change, Some Stay the Same. The Jerusalem Institute for Strategy and Security (JISS). Retrieved from https://bit.ly/2viE M6x. [Accessed 29 November 2018].

Louis WMR, Owen R (eds) (1991) Suez 1956: The Crisis and its Consequences. Oxford: Oxford University Press.

Lynch M (2012). The Arab Uprising: The Unfinished Revolutions of the Middle East. New York: Public Affairs. 
Macaron J (2019). The Eastern Mediterranean Gas Forum Reinforces Current Regional Dynamics. Arab Center Washington DC (ACW). Retrieved from https://bit.ly/2GBl csT. [Accessed 25 January 2019].

Orkaby A (2015) The 1964 Israeli Airlift to Yemen and the Expansion of Weapons Diplomacy. Diplomacy \& Statecraft 26(4): 659-677.

Perry EG (1984) Israeli Involvement in Inter-Arab Politics. International Journal of Islamic and Arabic Studies 1: 11-1 .

Podeh E, Kaufman A (2006) Arab-Jewish Relations: From Conflict to Resolution?, 93113. Portland: Sussex Academic Press.

Quandt WB (2005) Peace Process: American Diplomacy and the Arab-Israeli conflict since 1967. Washington DC: The Brookings Institution.

Rabinovich I (2003) Waging Peace, Israel and the Arabs, 1948-2003. Princeton: Princeton University Press.

Saikal A (2019) Iran Rising: The Survival and Future of the Islamic Republic. Princeton: Princeton University Press.

Schanzer J, Tahiroglu M (2016) Ankara's Failure, How Turkey Lost the Arab Spring. Foreign Affairs. Retrieved from https://fam.ag/1K8uYjJ. [Accessed 25 January 2016].

Sela A (1998) The Decline of the Arab-Israeli Conflict: Middle East Politics \& the Quest for Regional Order. Albany: State University of New York Press.

The Guardian (2006) Israel 'held secret talks with Saudi royal family. Retrieved from https://www.theguardian.com/world/2006/sep/25/saudiarabia.israel. [Accessed 25 September 2006].

Tisdall S (2011) Iran has been isolated by the Arab spring. The Guardian. Available at https://www.theguardian.com/commentisfree/2011/may/17/iran-arab-spring.

Vatikiotis PJ (1978) Nasser and His Generation. New York: St. Martin's Press. 
